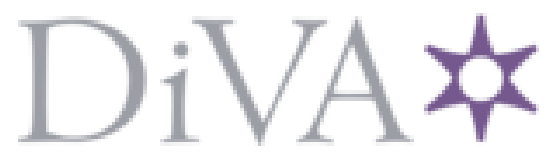

http://www.diva-portal.org

This is the published version of a paper published in International Journal of Entrepreneurial Venturing.

Citation for the original published paper (version of record):

Ghannad, N., Ljungquist, U. (2012)

Change of entrepreneurial agenda in a core competence context: exploring the transformation from technology focus to market focus.

International Journal of Entrepreneurial Venturing, 4(2): 148-167

https://doi.org/10.1504/IJEV.2012.046528

Access to the published version may require subscription.

N.B. When citing this work, cite the original published paper.

Permanent link to this version:

http://urn.kb.se/resolve?urn=urn:nbn:se:hh:diva-21752 


\title{
Change of entrepreneurial agenda in a core competence context: exploring the transformation from technology focus to market focus
}

\author{
Navid Ghannad \\ School of Business and Engineering, \\ Halmstad University, \\ P.O. Box 823, S-30118 Halmstad, Sweden \\ E-mail: navid.ghannad@hh.se
}

\section{Urban Ljungquist*}

School of Management, Blekinge Institute of Technology,

S-371 79 Karlskrona, Sweden

E-mail: ulj@bth.se

*Corresponding author

\begin{abstract}
The newest small firms - the start-ups in general and the international new ventures (INV) in particular - face major difficulties from the beginning. Not only do they need to bring competitively unique products to a new, highly competitive market, but they also must be successful in convincing customers of their products' benefits. This ultimate small firm test is in fact very similar to the criteria that define the core competence concept. Still, core competence matters have historically been delimited to large, preferably diversified companies.

In this paper, we apply core competence theory and entrepreneurship theories on a small firm's empirical context. We concentrate on technology focused INVs and on the change, or transformation, these start-ups must complete in order to adopt a more market-oriented focus. Without the transformation, we argue, the small firm will not be able to expand. The purpose of the paper is to explore parts of the processes changed during the transformation and to enhance our understanding of core competence applicability on small companies. We formulate propositions, empirically guided and theoretically anchored, that describe four different components that facilitate the small firm technology-to-market transformation.
\end{abstract}

Keywords: international new ventures; INV; international entrepreneurship; core competence; entrepreneurial competence; start-up; strategic change.

Reference to this paper should be made as follows: Ghannad, N. and Ljungquist, U. (2012) 'Change of entrepreneurial agenda in a core competence context: exploring the transformation from technology focus to market focus', Int. J. Entrepreneurial Venturing, Vol. 4, No. 2, pp.148-167.

Biographical notes: Navid Ghannad is a Lecturer and a Senior Doctoral Candidate in Marketing and Entrepreneurship in School of Business and Engineering at Halmstad University. He conducts research primarily in the area of international entrepreneurship. He has published his research in Frontiers of Entrepreneurship Research as well as journals such as International Journal of Entrepreneurship and Small Business. 
Urban Ljungquist is an Assistant Professor in Strategy and Innovation in the School of Management at Blekinge Institute of Technology. He conducts research primarily in the area of processes of strategy and innovation. He has published his research in journals such as European Business Review, Knowledge and Process Management and Management Decision.

\section{Introduction}

Core competence is one of the most well known concepts within the strategic management domain. It was initially developed for large companies to provide corporate guidance for further expansion into new markets with newly developed products, which by the 1990s was a popular area of research for achieving firm growth. Today, the core competence concept is acknowledged by scholars and adopted by practising managers as an indisputable source of competitive advantage and a stepping stone for firm growth (Drejer, 2000), even without the diversification aspects. In this paper, we adopt a straightforward procedure to define core competence by measuring a competence against three criteria: contribute significantly to the perceived customer benefits of the end product, be competitively unique, and provide potential access to a wide range of markets (Hamel and Prahalad, 1994; Prahalad and Hamel, 1990). This procedure was previously adopted in empirical studies (Ljungquist, 2008, 2006; McDermott, 2003).

Although the core competence concept was originally designed for large, diversified companies, we have not found evidence that the concept, conceptually or empirically, could not exist in a small company. Still, this is unknown territory since we lack understanding on core competence issues and empirical studies in the context of small firms. Small companies, International new ventures ${ }^{1}$ (INVs) and start-ups in particular seldom have obvious competitive advantages such as patents or cost advantages from scale or scope. Instead, they basically consist of the people in the firm getting the job done, which from the beginning may only be the entrepreneur and one or a few employees (Ghannad and Andersson, 2012). These people could be categorised as 'competencies', both individually and as a group. To achieve a competitive market position, or to enter a market, a start-up needs to rely on these competencies and must find a unique market position to begin delivering customer value (Schulz et al., 2009; Kraus et al., 2011). Finding a unique market position and delivering customer value are in fact two out of the three core competence criteria (previously mentioned) that separate a competence from a core competence. The third criterion is already built-in for a start-up: to enter a new market. Thus, we conclude that small companies (from the start-up phase) could hold a core competence and argue that this core competence is likely technology-based. The reason for the latter is that many goods-producing start-ups are based on the technological skills ${ }^{2}$ of the entrepreneur and occasionally of a few employees. From the empirical cases of this paper, we will outline how technology is the prime focus when the entrepreneur faces opportunities ${ }^{3}$ and satisfies previously unmet market demands.

The start-up enters a market to find a competitive position. The technological uniqueness of the start-up may be preserved for awhile; however, the technologies will probably need continuous development or else they will eventually become obsolete due to resource and competence erosion - ultimately due to competitive rivalry - when 
competitors imitate their success. As a start-up, a small company has limited abilities to protect itself from imitation. Even the patent process may be time-consuming and costly to enter. With limited financial resources, daily operations and investments take precedence over any other considerations. Sooner or later, the start-up needs to differentiate its product offerings to satisfy the customers' need. Therefore, the firm must be transformed from a technology focus to a market focus. This may be a challenging transformation for a technology-driven entrepreneur and the start-up firm, since a market (and marketing) focus is quite different from a technology focus [for instance, see Levitt $(1960,2004)$ for a review]. Existing research has highlighted some difficulties involved in small firm and market issues. Empirical studies have resulted in different patterns of market behaviour among smaller firms compared to the larger counterparts, such as customer relations (Gilmore et al., 2001). Scholars also infer that a lack of market focus may be a dominant reason for small firm failure (McGaughey, 1998).

This paper aims to explore how three different start-up firms have transformed from an initial technology-based to a market-based focus. More specific, we will scrutinise the problem: which main components ${ }^{4}$ of the start-up firm are transformed when its focus is changed from technology to market. ${ }^{5}$ The purpose of the paper is to explore the change process during the transformation to enhance our understanding of core competence applicability on small companies. This empirical study contributes to entrepreneurship theory and to strategic management theory - the latter in particular contributes to the resource-based view and the core competence-based literature - and is significant for research and for practical matters in developing and specifying the concept of core competence in an entrepreneurial setting.

\section{Theory}

\subsection{Entrepreneurial concepts}

Empirical findings indicate that sustained competitive advantage may come from three kinds of basic competencies: innovation competencies, manufacturing competencies and marketing management competencies (Rangone, 1999). These competencies are closely related to the entrepreneurial resources, as Penrose (1959) termed it, referring to the risk and drive of the managers who are responsible for the growth of the firm. The notion of entrepreneurial competence as a set of competencies to succeed in their entrepreneurial activities is widely recognised by scholars (Bird, 1995; Chandler and Jansen, 1992; Hood and Young, 1993). Previous studies have been conducted in which the concept of entrepreneurial competency has been the guiding principle of analysis (Bird, 1995). Entrepreneurial competence is regularly defined as the set of knowledge, skills and abilities that enable an entrepreneur to successfully perform their job (Baum et al., 2001; Chandler and Hanks, 1994a; Man and Lau, 2000; Man et al., 2002).

Over the past two decades, a number of researchers have tried to explain entrepreneurial competence and a company's ability to sense, act and mobilise in a competitive market (see e.g., Mitchelmore and Rowley, 2010 for a review). A majority of these studies have focused on individual entrepreneurs and their traits. Examples of these traits mentioned in existing literature are risk taking, attitude, need for achievement, activity, tolerance of ambiguity, resistance to change, reflectiveness, impulsiveness, locus of control, and a motivation to create growth (Halikias and Panayotopoulou, 2003). 
To sense and adapt to uncertainty characterises a critical entrepreneurial resource (Ireland et al., 2003; Krauss et al., 2005; McGrath and MacMillan, 2000). Still, scholars researching in the field of entrepreneurship usually distinguish between managerial competencies and entrepreneurial competencies (Chandler and Hanks, 1994a, 1994b; Lerner and Almor, 2002). It is suggested that entrepreneurial competencies are needed to start a business, while managerial skills are needed to grow the business (Man et al., 2002). It is interest and the entrepreneurial competence that results in the birth of a company, but additional competencies are required, as the founder must change his role from an entrepreneurial competence to a market focused competence in order to maintain successful business growth (Churchill and Lewis, 1983).

\subsection{Core competence concept}

The core competence concept was originally defined as: "The collective learning in the organisation, especially how to coordinate diverse production skills and integrate multiple streams of technologies" [Prahalad and Hamel, (1990), p.82]. The definition's notion is fairly clear. Still, for practical issues, such as operationalisations, it is not clear enough (Bogner et al., 1999), especially with regard to issues of identification (Collis and Montgomery, 2005; Ljungquist, 2008). In this paper, we use the more straightforward definition previously mentioned and initiated by Prahalad and Hamel (1990).

A majority of the existing core competence literature focuses on issues of identification. In fact, some scholars suggest that core competence research should begin with identification (Clark, 2000). Petts (1997), for instance, proposes identification of the customers' future needs as drivers of competitive advantage in a "core competence engine"; however, other scholars propose identification through a "process oriented core competency identification" model (Yang et al., 2006). Scholars also propose different multiple-step managerial processes to identify and assess current successful competencies (e.g., Hafeez et al., 2002; Javidan, 1998). One researcher, for example, developed an eight-step managerial model (Javidan, 1998), while others advocated for employee task forces (Eden and Ackermann, 2000; Prahalad and Hamel, 1990). Other scholars have proposed that the core competence concept consists of three components (Wang et al., 2004) - marketing, technological and integrative competencies - and measure the effects of those components on a firm's performance.

In this paper, we partly draw on previous research on identification. Due to the selected core competence definition - being a special type of competence - we ought to also include the theoretical ideas behind the competence concept. ${ }^{6}$ The competence concept is generally separated into functional competencies and integrative competencies (March, 1991; Henderson and Cockburn, 1994). The functional category is used in daily activities and is of interest for this paper since it is further subdivided into technological and market competence (Danneels, 2002). Furthermore, we acknowledge the importance of internal structure (Nelson and Winter, 1982; Winter, 2003), which is found in internal routines, systems, and explicit visions and plans for a firm. Previous empirical research in large companies shows how internal structures support development and the transformation of core competencies (Ljungquist, 2006, 2008).

In the following paragraphs, we outline how data were collected and analysed, before presenting the empirical cases and the following discussion and conclusions. 


\section{Methods}

This exploratory study was conducted in three independent cases of small INVs. The case method facilitates a deeper understanding of the context (Yin, 2003) and is important for general core competence understanding (Eden and Ackermann, 2000). The main data sources of this paper were primary data and secondary data, both of which were collected between 2000-2007. The primary data consist of a total of 65 personal interviews with 38 respondents. The selection of respondents was achieved through snowball sampling. Potter (1996) describes the snowball technique as one that begins with a purposive sample in which key informants who can provide important insights are selected. Snowball sampling can be placed within a wider set of link-tracing methodologies that seek to take advantage of the social networks of identified respondents and provide a researcher with an ever-expanding set of potential contacts (Spreen, 1992). This process is based on the assumption that a 'bond' or 'link' exists between the initial sample and others in the same target population, allowing for a series of referrals within a circle of acquaintances (Berg, 1988). Besides the owner, managers, former employees, business partners, friends, family members, suppliers, and customers were interviewed. The interviews were informal and done in person, and the interview guide consisted of open-ended questions. Respondents were, for instance, asked to describe the firm's business from both technology and market perspectives, and from entrepreneurial and competence perspectives. They were also asked to describe the firm's most important competencies and resources, for instance how they had developed and were being used. The locations of the interviews depended on the respondents and were held in multiple countries. Each interview was between one and four hours, and were recorded, transcribed and sent out to the respondents for correction and verification.

Secondary data were collected through annual reports, internal reports, photographs, newspaper articles, memos, and contracts. If available, other academic studies (undergraduate and/or graduate) investigating the case companies have been used as secondary data. This heterogeneous approach enhances multiple facets and facilitates comprehension and analysis, and has a twofold purpose: first, to enrich the empirical case with thick descriptions, which improves its trustworthiness and enhances content validity (Rouse and Daellenbach, 1999); and second, to enhance reliability by triangulating the data and method (Creswell, 1994).

\subsection{Analysis}

The analysis of qualitative data consists of data reduction, data display and conclusion drawing/verification, according to three concurrent flows of activity (Miles and Huberman, 1994).

Data reduction refers to the process of selecting, focusing, simplifying, abstracting, and transforming the data that appear in written field notes or transcriptions. The reduction of the empiric collected for this study began immediately after an interview. The data reduction at this stage is the process of identifying, coding and categorising the primary patterns in the data; in other words, analysing the content of interviews, documents and the observations. The analysis began by reading through all of the field notes from the interviews and the documents and then dividing them up. Since there are three cases with multiple respondents in each, it was important to synchronise and 
categorise their answers to maintain a logical flow. The structure and coding was done according to the outline of the theory. Data display is the second major flow of analysis activity. Generally, a display is an organised, compressed assembly of information that permits conclusion drawing. For qualitative researchers, the typical mode of display has been extended, unreduced text usually in the form of written field notes, which the analyst scans through, attaching codes and then extracting coded segments and drawing conclusions. The third stream of analysis activity is conclusion drawing and verification. It is at this stage that the researcher begins to decide what things mean by noting regularities, patterns, explanations, possible configurations, casual flows, and propositions.

Data analysis is widely recognised as the most difficult and least structured area of case study research (Eisenhardt, 1989). To overcome this weakness, two forms of analysis were used. Results of this study were analysed from a within-case perspective and a cross-case perspective. In the within-case analysis, the evidence from each of the three cases was analysed separately utilising the frame of reference as a basis. This frame, which is a combination of theories on the areas of entrepreneurship and strategic management, helps us understand the case. Any similarities or dissimilarities compared to the frame of reference and to the theoretical framework will be the findings of the within-case analysis. Once the within-case analysis is complete, a cross-case analysis will be initiated to uncover cross-case patterns. Consequently, the analysis will focus on issues and aspects that can only be understood by comparing the cases. For validity reasons, the findings were written in case report of which the next section of this paper is an excerpt. Most of the respondents independently read through their transcripts and corrected this report before writing the final draft of the case. The findings were also verbally presented and discussed with colleagues.

\section{Description of the initial competencies}

\subsection{Case Liko}

Liko AB is located in Alvik, a small village with 770 citizens in Northern Sweden. The company specialises in developing, manufacturing and marketing lift and transfer equipment to people whose mobility is impaired. The main products are patient lifts - stationary, mobile and horizontal. In addition, there are an assortment of covers - slings, leg extenders and other accessories for heavy lifting. This is a niche market with about 20 major players worldwide. The company was founded in 1979 by the entrepreneur. Today, the company, including its subsidiaries, employs over 300 people with a turnover of more than $€ 50$ million. Liko is the third largest company within this segment with about $20 \%$ of the world market share. Before establishing Liko, the entrepreneur spent 13 years as an employed inventor at the regional health council, travelling with occupational therapists and physiotherapists to construct individual aids for the handicapped. He explains:

\footnotetext{
"These 13 years were the best school for me. I was able to learn the needs and limits of both those who we helped (i.e., disabled) and those that were helping (i.e., therapists). I was also able to learn the 'language' used in healthcare, which isn't the same as in engineering. With both these skills, I had a great advantage in developing new solutions."
} 
This experience became applicable when establishing Liko during the final years as an employed inventor. Since the birth of the firm, the entrepreneur has focused on technology to solve technical problems and dilemmas. One example of his technology interest, besides being able to have high quality products, is that he wanted to buy the best manufacturing machines available:

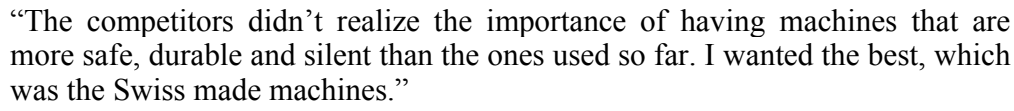

During the company's initial year, technological competence was dominating the firm. The initial prototypes of the manufactured lifts were superior to the competitors', since they included highly advanced technological solutions. However, hospital management (the decision maker in the purchase process) and therapists (end users) could not understand all of the advanced functions. The entrepreneur was essentially forced to simplify the product.

During the initial years, the entrepreneur also developed a sense for customer satisfaction and that a customer may have different roles. Not only did he look at the technical solutions he could invent, but also at the need of the disabled, the therapists, the prescribers, and the buyers that ultimately would purchase the new products. In fact, it was not the price that attracted customers to buy the firm's products, but the fact that Liko's products were more consumer friendly, safer and they made less noise than the competitors' products.

From the case description above, we can conclude that technology is in focus. A more detailed categorisation is more difficult to make, yet a concentration on R\&D is obvious. Thus, we can summarise that the case company Liko's technology core competence is R\&D-oriented.

\subsection{Case Polaris}

Polaris $\mathrm{AB}$ is a privately owned niche company that manufactures and sells rimless eyewear. The headquarters are located in northern Sweden, and it was here that the entrepreneur and present owner started the company in 1979. The size of the Polaris Group has been constant over the past decade, with around 60 to 80 people employed. The turnover of the group has, however, increased significantly during the past decades. In 1981, the group had a turnover of $€ 1$ million, while today the turnover is approximately $€ 9$ million. Almost $95 \%$ of the total sales are generated at international markets. Japan and the UK are the two most important markets, which are generating almost $65 \%$ of the company's sales.

During his childhood, the Polaris entrepreneur worked in his father's optical store. Opticians are generally only involved with fitting glasses into already designed frames, which were something he already had a taste for: as a young teenager he designed a pair of frames and put it among the others in his father's store, selling it as the "latest fashion from Paris". Several years later, he opened an optical store of his own in another town. He resumed his interest in design and in 1975 designed a pair of plastic frames, which he believed would be the future in eyewear. In 1976 and several product development iterations later, the plastic glass made a strong entry into the market. It was even possible to purchase the glasses in various colours. The Polaris entrepreneur was a pioneer in learning how to use and colour this new material. During the start-up process, he also 
solved the manufacturing problem that had been haunting the frameless eyewear manufacturers for several decades. Previously, the few frameless eyewears available in the market were unfortunately quite fragile and the optical glasses could crack easily, as the frames were attached directly on the glass. The Polaris entrepreneur did manage to use an alternative, more technologically advanced manufacturing method, as well as other materials (soft screws) that solved the problem. From the case description above, we can conclude that technology, just as in the Liko case, is in focus. Furthermore, the technology core competence identified here is also on R\&D issues.

\subsection{Case Index}

Index is a privately owned company that manufactures and sells high quality and technically advanced Braille printers. The company is located just outside one of the largest towns in northern Sweden, and is the world leader in selling single- and double-sided Braille embossers with high printing speeds. The company was established in 1982 by the present owner and currently employs 12 people with an annual turnover of approximately $€ 4$ million. Today, $97 \%$ of the firm's total sales are exported to around 80 countries in the world. The firm's largest export markets are USA, Canada and Europe, which account for $70 \%$ of their exports.

In the late 1970s, when personal computers made their entry, the Index entrepreneur got the idea of developing an affordable and portable Braille printer. The idea originated after observing the efforts of his blind mother, a secretary at the local blind association, typing the same document ten times on the Braille typewriter. The entrepreneur, who ever since childhood had made multiple blind aid inventions for his mother, began investigating the possibility for such a product. The product idea was interesting for most individuals and organisations since, "At this time, the cost of a computer was as much as for a new car", the Index entrepreneur explains. However, the entrepreneur was not alone on this idea. In the beginning of 1980 s, there were several companies and universities that were developing the same kind of Braille printer.

$$
\begin{aligned}
& \text { "Of course we were under pressure", the Index entrepreneur says about the } \\
& \text { start-up phase. "You shouldn't do what I did if you follow the schoolbooks. To } \\
& \text { develop a high technological product that requires an international market with } \\
& \text { almost no financial resources and no knowledge of the market was just crazy." }
\end{aligned}
$$

The Index entrepreneur's advanced engineering skills contributed to the technological developments needed to invent such a product. He never considered his product as finished. When he eventually ran out of financing, selling the product became 'a necessary evil' to facilitate and continue technology development. The technology core competence identified for this case is definitely R\&D focused.

In the next section, we advance the discussions of the cases further and in more detail.

\section{Discussion}

While all three cases are located in Sweden with a small domestic market, the motives for the companies' internationalisation has, initially, been more proactive (in other words managerial driven) rather than reactive at the early establishment and internationalisation process. Within this process a transformation of the core competence manifests itself. 
Considering the three cases as a whole, four aspects have facilitated the transformation of technology core competence to market core competence. They are: networks (with a competence to build a personal network, the start-up entrepreneurs could make swift market penetration with the products, which most likely have not been possible from the technology competence alone); organisational structure (vital support for core competencies. The structure seems more crucial in particular contexts such as expanding businesses and in dynamic environments, actions typical for a start-up); added market competence (the importance of not abandoning a technology foci when entering new markets and when the market is expanding fast. Instead, the technology focus and the market focus seem to work best in combination when not substituting each other); and initial external funding (the need for initial funding from external parties pushed the entrepreneurs to 'sell' the firm and its products to industrial non-specialists, which here infers a need to be very convincing in arguing for the comparative products' benefits compared to existing solutions).

\subsection{Transformation from networks}

During the product development process, the Index entrepreneur used his social network and asked his colleagues to help him with electronics and funding, and former university teachers to help with the design of the products. When the prototype was finished, friends and family members helped him to manufacture and promote the product. A childhood friend that spoke French fluently was employed at the firm to promote the French market and to write the instructor manuals in French. Also, during the firm's early internationalisation process, the Index entrepreneur randomly travelled to meet distributors at trade shows. The technology solutions and the unique size and price of the printers helped open doors to new customers, who were highly interested in the innovative product. This boosted the interest for the Index firm as well. During customer interactions and product demonstrations, the Index entrepreneur also established a more professional network among potential customers. The network also helped develop mutual trust between the distributors, agents and resellers, who were all beneficial for the small firm in marketing the innovative and new products. As a result, the Index entrepreneur could be more selective when choosing the best markets and distributors for his business relations. Thus, the personal network the Index entrepreneur established was a major reason for the swift market penetration of his products.

As a youngster, the Polaris entrepreneur enjoyed meeting and talking to people he did not know, for instance during summer vacations he helped tourists with food, maps, tips for must-sees, and so on. During these years, besides improving his English he also learned about different cultures, customs and traditions, and, most importantly, how to deal with different nationalities. He also established major personal network connections. Later, before establishing Polaris, he was a board member of the largest optical chain in Sweden (Synsam), where he also worked as a buying manager. For a period of time, he was able to travel to major trade shows in Europe and meet eyewear suppliers, thus further developing his business network. This network, along with his international friends he made earlier in life, soon became important in Polaris's international growth plan. A major problem, however, was that neither the entrepreneur nor any of the employees had any international selling experience. Basically, they did not know where to start the internationalisation process. Fortunately, the entrepreneur's personal network became a stepping stone: when he visited his friends he also asked for advice on partners 
in distribution, selling and so on in the focal country. After five years as an established company, Polaris was represented in over 18 countries on four continents.

The first five foreign markets that were entered within the first year of establishment were directly due to acquaintances, family members and friends that were active or had knowledge of those markets. The Polaris entrepreneur's sister, for example, worked as a professional ballet dancer in England. While working in London, she married a man who used to work as a product developer at an English optical production facility before changing professions and becoming a teacher. This man became the reason for Polaris's entrance into the UK market.

As mentioned earlier, the Liko entrepreneur was an employed inventor, and he travelled and worked closely with therapists in the healthcare industry for 13 years. The network he developed during this time was of great importance and it worked as an 'idea generating input' in developing products. Yet, even more importantly it worked as a catalyst for promoting and selling the new products. In fact, all employed sellers and agents were active as occupational or physiotherapists. Furthermore, the Liko entrepreneur also used his brother's knowledge in export sales from a Swedish multinational company, as well as other friends and acquaintances, to boost foreign selling. For example, the early entrance into the US and Canadian markets was merely due to the fact that the Liko entrepreneur was invited to a dinner party at his brother's house where he met a successful Swedish executive living in the US. This meeting resulted in Liko entering the US market, which eventually became the company's largest.

We have just presented a few cases of networks being important and beneficial for market and marketing issues. Defined as a sub-set of the entrepreneur's total social network, Johannisson (1993) explains that the nature of an action set at pre-start-up time T1 will have changed by start-up time T2 due to the entrepreneur's social network being actively involved with the entrepreneur in achieving a new venture start-up. Our finding is also in accordance with Butler and Hansen (1991), and Greve and Salaff (2003), who suggest that many emerging entrepreneurial firms rely initially on close, relationally embedded ties with family and friends, in particular in the pre-start-up phase. All of the cases had strong technology competencies, presenting innovative product solutions and setting new industry standards. This, of course, is a major reason for the start-up firms' success. Yet, with the competence in building and maintaining a personal network, the start-up entrepreneurs made swift market penetration with their products, which most likely would not have been possible from technology competence alone. Thus, we are ready to propose the first proposition: a start-up firm, which holds both technological and network-building competencies, makes a faster transformation from a technology focus to a market focus.

\subsection{Transformation from organisational structure}

Index holds several strengths compared to their larger competitors. The entrepreneur explains:

"There is a huge difference between us and our competitors around the world. First of all, we have better prices, printers with higher performance and smaller sizes. Furthermore, we are the only company offering a total solution; all others are delivering the printer and then it is the customer's responsibility to buy the correct software, install it on the server and so on. We are not only selling the 
product but also delivering the service around it. This has always been [the firm's] strategy."

However, the 'total solution' package does not emerge by itself. Instead, the entrepreneur and the employees of Index worked hard to accomplish organisational structures and build routines and systems to smooth the firm's progress in product and market development. One example concerns $\mathrm{R} \& \mathrm{D}$, a function wherein Index has been very successful. The entrepreneur explains the success:

\begin{abstract}
"Many of our competitors are amazed over how Index, which has one-fourth to one-third the amount of people employed at R\&D [function] compared to them, is still performing better. The secret lies in the development of platforms. If you have the right structure then one person can accomplish a lot. But if you have the wrong structure it doesn't matter how many people you are because they still cannot accomplish anything."
\end{abstract}

Thus, the organisational structure has been vital for the technological development in Index. The Liko entrepreneur was advised to write down all of his thoughts and ideas for the firm and distribute it to all employees:

\begin{abstract}
"It was obvious that as long as I haven't written down my opinions, no one else could know what I thought. In my opinion this advice was very wise. That same evening I sat down and wrote down all my thoughts."
\end{abstract}

That evening's writing resulted in a book called the "Little Green Book of Liko", which outlined 42 premises for the firm and its strategies.
"According to this book, all strategies-including collaboration, production, investment, customer, production, and PR - should have growth as their focus. This book was and still is our guiding star, which explains how to manage moral and ethical problems, as well as how to develop our thinking in the firm. It has also kept the company together and is very appreciated by the employees," explains the entrepreneur.

The above are examples of how organisational structure has been vital for the expansion of a start-up firm. Previous research on core competence shows that a company structure - systems and routines - is vital for supporting core competencies (Ljungquist, 2007). The structure type seems more crucial in particular contexts such as expanding businesses and dynamic environments, which seems typical for a start-up. An empirical study has identified several different structure types: administrative and computer systems; daily routines and operations; and explicating company visions and goals in communication (Ljungquist, 2008). Thus, we are ready to suggest the second proposition: a start-up firm with a technology focus within a firmly structured organisation (which here implies use of supporting systems and routines), and with a growth plan for the firm, makes a faster transformation from a technology focus to a market focus.

\title{
5.3 Transformation from added market competence
}

When the product was finalised and ready for market launch, the Index entrepreneur started to look for opportunities to sell the printer abroad:

"I knew from the beginning that this product must be sold abroad. The Swedish market was too small. You cannot survive in this business without exporting. You could not have a business and only concentrate on the [domestic] market, in which [we] would sell 40 printers annually. There was lots of money and 
opportunities. Our machines cost [only] one-third of the competitors'. We made a revolution in this business. It was exciting to be there and making a difference."

The international process, however, is far from simple, and several times, due to the complexity of paperwork and lack of information, Index had to use the Swedish Trade Council. However, the entrepreneur was not happy with the results:

\begin{abstract}
"We used the Swedish Trade Council in the beginning; however, it didn't work out [very well since] they are not made for helping small firms. They too must learn the market. And since they have no experience in the [focal] market, it is cheaper and more efficient to call one colleague in the same market, yet with products that are not competing with ours."
\end{abstract}

The international endeavours took several turns for Index. A first attempt with the trade council experts was a failure. Yet, the Index entrepreneur was persistent since he understood the importance of the market competence to successfully attempt internalisation. He originally asked a distant competitor for help. Previous research also supports the idea that start-ups and small firms do not categorise firms supplying similar products as competitors but as colleagues, as the quote above explains (Pacitto et al., 2007).

The vast product development in Liko has led to problems with other companies copying their products. A quick review of the main competitors' websites does support the entrepreneur's argument that Liko is the leading company in introducing new products to the market. The entrepreneur believes that from a competitor's perspective, Liko is the most interesting company because they are introducing many new and innovative products with clever solutions that decrease price and increase functionality and security. In such cases it is easy for their competitors to use Liko's ideas for developing their own products. One difficult competitor is the Swedish world leader Arjo. However, as the entrepreneur explains:

\begin{abstract}
"They are bigger than us but much worse in product development. This company has stagnated and its growth is inhibited. Also, their products are more expensive and have worse quality and safety measurements. The high price has been part of their image, but the customers have started to realise their bluff. In this case, big is not beautiful."
\end{abstract}

The entrepreneur spent four years at ABB (formerly ASEA). During that time, he had the opportunity to participate in many interesting projects. For example, the company sent him to Italy to negotiate with the board of Italian railways for new switchyards:

\begin{abstract}
"I was only 22 years old and didn't even own a suit. I admire ASEA for sending me on such an important mission. I remember the negotiation room where I was sitting alone on one side and at least 20 Italians on the other side. However, once you have managed to get them to sign the order book, you are better than the best students at Harvard Business School. I was away for a week. This was the first time for me outside Nordic countries and it was a great experience."
\end{abstract}

This event brought sales and marketing experience and understanding to the Liko entrepreneur, who was insightful enough to understand his limitations in market competence matters. Yet, his basic market competence was enough for him to take an active part in trade fairs in the other Nordic countries, and soon the firm had established long-term relationships with distributors in Denmark, Norway and Finland. However, as 
Liko started to further internationalise, the entrepreneur discovered that the firm needed more advanced market competencies, particularly in exporting. Therefore, in 1986 he asked his older brother to join the company as export manager because his experience with exporting and foreign sales at ABB would be beneficial to Liko's internationalisation.

An important issue worth noting is that the Liko entrepreneur, when developing new products, was thinking not only as a product developer but also as a marketer and businessperson. For instance, the entrepreneur restrained himself many times from certain $R \& D$ investments. In his opinion:

\begin{abstract}
"You may develop yourself to death since every product can be developed for eternity. You must consider that every development or modification you do is an investment, and if the product can't revenue that investment then you must restrain yourself from doing it. I have thousands of good ideas but must screen them and then select one or two. This is what I did with the 'furniture extender', which after 15 years is still one of our bestsellers and every year wins lots of different tests and comparisons."
\end{abstract}

Thus, the entrepreneur has not only discovered his own limitations in market competence (as when hiring his elder brother as export manager), but he is also delimiting his own drive for technological perfection in $R \& D$ processes when passing over further product developments due to an expected restricted market payoff. This example also stresses the importance of not abandoning the technology focus when entering new markets, especially when the market is quickly expanding. Instead, the technology perspective and the market perspective seem to work best in combination when not substituting for each other. The combination is, naturally, more common in large firms. Previous empirical studies, however, have found that there is more to the issue of combination: a company's market orientation was not only beneficial to gain access to customers per se, but also to receive input to future developments in the existing technologies (Ljungquist, 2008). Thus, for a small firm with limited resources lacking access to market competencies, but with a (technology developed and completed) product ready to launch to market, it may be tempting to substitute technology competencies for market competencies. For a short-term strategy, the shift may be beneficial. For a medium- and long-term strategy and competitiveness, however, the result may be redundant technology competencies. We are now ready to suggest the third proposition: a start-up firm that adds market competence to the existing technology competence, instead of substituting the latter with the former, makes a faster transformation from a technology focus to a market focus.

\title{
5.4 Transformation from early external funding
}

Although the index entrepreneur was very skilled in mechanics and preferred to work solo in the technology development phases, he invited external parties to join his network to develop parts he did not master, for instance in electronics, software and in design issues. As he could not pay them for their services, he was forced to sell the idea and the prospects and give them stock shares in the Index firm, which at that time had no activity or value. Furthermore, at a later stage of the firm's expansion phase, the entrepreneur managed to convince a governmental agency (Tillväxtverket ${ }^{7}$ ) to lend the firm financial resources because it was in urgent need of funding to continue the product development process. 
The Liko entrepreneur had a similar experience with a lack of financial resources. At first he did borrow as much as he could on his property, house and car. However, this was not enough and he needed to convince his father to pawn his property in order for the bank to lend additional capital. At a later stage, once the first prototype was finished and additional funding was needed to manufacture the product, he needed to convince the same governmental agency (Tillväxtverket), the regional development funds and his bank that the prototype he had built was superior to the existing products in the market. Furthermore, he had to convince them that this was a major market potential and that they should invest. The first prototype, which the Liko entrepreneur calls 'a really ugly machine', was installed at a local health centre. It was due to this prototype demonstration that he managed to rise funding shortly after, followed by a huge order of 100 lifts for other healthcare providers. This was the springboard for and the start of Liko.

Similarly, the Polaris entrepreneur has also been forced to use external funding to develop his company. When he started the company, he was in need of new production facilities, which was after much negotiation and persuasion finally financed with funding from NUTEK, the local development agencies and some local banks. These lenders and credit institutes, however, demanded a professional board of directors in the firm and not merely his wife and kids. With a professional board, the Polaris entrepreneur was further forced to have a market focus and on a regular basis present his progress to the board. Such a finding is in accordance with prior empirical studies that identified the role of external financers in supporting the new firms (Fried et al., 1998; Gabrielsson and Huse, 2002). We are now ready to suggest the fourth and last proposition: a start-up firm with a technology focus that initially needs external funding makes faster a transformation from a technology focus to a market focus.

\section{Conclusions}

This paper aims to empirically describe how different types of start-ups have transformed from an initial technology-based focus to a market-based focus. We develop our understanding by applying strategic management theories of core competence on an INV empirical context, and, accordingly, we contribute to the research streams of both core competence and entrepreneurship.

We were interested in, firstly, to find out whether the core competence notions are applicable to small firms, and if so, secondly, how the core competence of the firm changed during a major technology-to-market transformation. The underlying line of thought is that a small firm that enters a new market must bring customer benefits and be competitively unique to stay in the business. These three aspects infer that a small firm, or more precisely a start-up, automatically fulfils the core competence identification criteria. We conclude that the core competence notions are applicable to small firms.

Furthermore, the chosen empirical context concentrates on technological competencies, which we argue is typical for many small firms. The transformation from a technology focus to a market focus is especially crucial to a small firm, since such a firm has limited resources (e.g., in finance) to protect against competitors' plagiarism. Prior to entering a market, the small firm could rely on advancements in technology and preparing the product for the market. After market launch, however, the start-up must put most of its resources into selling and marketing activities, and, of course, to 
manufacturing the products. For these reasons, innovations from start-ups are easy targets for larger firms' technology copying.

This paper also carries out one of the first core competence studies on an INV empirical context. The reason for performing this was to find out how the basic core competence conceptions changed during a typical small firm transformation. We explored how core competence-related parts changed during the transformation in order to enhance our understanding of core competence applicability on small companies. The theoretical discussion combined with the empirical descriptions resulted in a discussion and a formulation of propositions. From the discussions and propositions we draw the following conclusions:

- One: A start-up firm, which holds both technological and network competencies, makes a faster transformation from a technology focus to a market focus. A small start-up firm seldom has the financial resources or the time to develop market-based competencies, for instance to establish and to develop distribution channels and new customer relations. This adds to the prior empirical research (e.g., Butler and Hansen, 1991; Greve and Salaff, 2003) and sheds further light on the fact that network competence may be a catalyst that boosts technology transformation through help from the network.

- Two: A small firm with a technology focus and a well-structured organisation (which here implies use of supporting systems and routines), and with a growth plan for the firm, makes a faster transformation from a technology focus to a market focus. The organisation's structure not only simplifies daily routines, but it also prepares for a forthcoming firm expansion (Nelson \& Winter, 1982; Winter, 2003). The notion of supporting structure being beneficial to firm development is also in line with previous empirical studies on core competence in large companies (Ljungquist, 2006, 2008).

- Three: A start-up firm that adds market competence to the existing technology competence, instead of substituting the latter with the former, makes a faster transformation from a technology focus to a market focus. Scarce financial resources and time constrains due to limitations in the size and scopes of the task force (employees) make it tempting for the entrepreneur to substitute competence rather than add to it. This may be the beginning of the end for a start-up firm if the long-term development in the technology competence permanently or temporarily is abandoned and replaced by a short-term focus on establishing a market competence. This adds to previous research in large firms, where Ljungquist (2008) discovered how market competence was a catalyst for technology core competence development.

- Four: An INV firm with a technology focus that initially needs external funding makes a faster transformation from a technology focus to a market focus. Prior empirical studies (e.g., Fried et al., 1998; Gabrielsson and Huse, 2002) have identified external financers for assisting the firms in their market orientation. Yet, the results of this study also indicate that the start-up is already content with presenting the business model, product, concept, and so on for an external audience, in other words to 'sell' the technology. Therefore, the initial transformation towards a market focus is already taken when trying to present and convince friends and family, banks, and other external investors - as well as when signing contracts, 
making verbal and written presentations, producing prototypes, completing product tests and certifications, making demonstrations, visiting trade fairs, and so on - to secure external financing. As a result, the companies can leapfrog from a technology focus to a market focus much faster.

\subsection{Practical implications}

In this paper, we have highlighted four aspects that are critical for a successful core competence transformation from technology to market. For a small-firm entrepreneur, and in particular for start-up endeavours, the four aspects could guide installation and firm development by: making use of the network for adding initial market competence to the firm; adding daily routines and explicating the firm's growth plan to ensure the employees strive towards the same goal; not replacing an existing technology competence with a new market competence, since it could have severe long-term effects; and using external funding presentations for practising the marketing and selling procedures.

\subsection{Further research}

The focus of this study has been to examine the initial transformation from a technology to a market focus of the start-up and the early internationalisation of INVs. We still lack understanding on the forthcoming transformations throughout the life cycle of the small- (and later) medium-sized firm. We need to enhance our understanding of whether the evolution to market-oriented core competence is the final transformation, or if the firm's core competence will continue to change over the firm's lifespan, for instance involutes back to a technological focus.

\section{References}

Baum, J.R., Locke, E.A. and Smith, K.G. (2001) 'A multidimensional model of venture growth', Academy of Management Journal, Vol. 44, No. 2, pp.292-303.

Berg, S. (1988) 'Snowball sampling', in Kotz, S. and Johnson, N.L. (Eds.): Encyclopaedia of Statistical Sciences, I Vol. 8, John Wiley and Sons, Chichester.

Bird, B. (1995) 'Towards a theory of entrepreneurial competency', Advances in Entrepreneurship, Firm Emergence and Growth, Vol. 2, pp.51-72.

Bogner, W., Thomas, H. and McGee, J. (1999) 'Competence and competitive advantage: towards a dynamic model', British Journal of Management, Vol. 10, No. 4, pp.275-290.

Burgel, O. and Murray, G.C. (2000) 'The international market entry choices of start-up companies in high-technology industries', Journal of International Marketing, Vol. 8, No. 2, pp.33-62.

Butler, J. and Hansen, G.S. (1991) 'Network evolution, entrepreneurial success, and regional development', Entrepreneurship and Regional Development, Vol. 3, pp.1-16.

Chandler, G.N. and Hanks, S.H. (1994a) 'Founder competence, the environment, and venture performance', Entrepreneurship: Theory \& Practice, Vol. 18, No. 3, pp.77-90.

Chandler, G.N. and Hanks, S.H. (1994b) 'Market attractiveness, resource-based capabilities, venture strategies, and venture performance', Journal of Business Venturing, Vol. 9, No. 4, pp.331-350.

Chandler, G.N. and Jansen, E. (1992) 'The founder's self-assessed competence and venture performance', Journal of Business Venturing, Vol. 7, No. 3, pp.223-237. 
Churchill, N.C., and Lewis, V.L. (1983) 'The five stages of small business growth', Harvard Business Review, Vol. 61, No. 3, pp.30-40.

Clark, D. (2000) 'Implementation issues in core competence strategy making', Strategic Change, Vol. 9, No. 2, pp.115-127.

Collis, D. and Montgomery, C. (2005) Corporate Strategy: A Resource-Based Approach, 2nd ed., McGraw-Hill/Irwin, New York.

Creswell, J. (1994) Research Design: Qualitative and Quantitative Approaches, SAGE Publications, Thousand Oaks.

Danneels, E. (2002) 'The dynamics of product innovation and firm competences', Strategic Management Journal, Vol. 23, No. 12, pp.1095-1121.

Dimitratos, P., Johnson, J., Slow, J. and Young, S. (2003) 'Micromultinationals: new types of firms for the global competitive landscape', European Management Journal, Vol. 21, No. 2, pp.164-174.

Drejer, A. (2000) 'Organisational learning and competence development', The Learning Organization, Vol. 7, No. 4, pp.206-220.

Eden, C. and Ackermann, F. (2000) 'Mapping distinctive competencies: a systemic approach', Journal of the Operational Research Society, Vol. 51, No. 1, pp.12-21.

Eisenhardt, K.M. (1989) 'Building theories from case study research', Academy of Management Review, Vol. 14, No. 4, pp.532-551.

Fillis, I. (2001) 'Small firm internationalisation: an investigative survey and future research directions', Management Decision, Vol. 39, No. 9, pp.767-783.

Fried, V.H., Bruton, G.D. and Hisrich, R.D. (1998) 'Strategy and the board of directors in venture capital-backed firms - venture capital and high technology', Journal of Business Venturing, Vol. 13, No. 6, pp.493-503.

Gabrielsson, J. and Huse, M. (2002) 'The venture capitalist and the board of directors in SMEs: roles and processes', Venture Capital: An International Journal of Entrepreneurial Finance, Vol. 4, No. 2, pp.125-146.

Ghannad, N. and Andersson, S. (2012) 'The influence of the entrepreneur's background on the behavior and development of born globals' internationalisation process', International Journal of Entrepreneurship and Small Business, Forthcoming.

Gilmore, A., Carson, D. and Grant, K. (2001) 'SME marketing in practice', Marketing Intelligence \& Planning, Vol. 19, No. 1, pp.6-11.

Greve, A. and Salaff, J.W. (2003) 'Social networks and entrepreneurship', Entrepreneurship, Theory \& Practice, Vol. 28, No. 1, pp.1-22.

Hafeez, K., Zhang, Y. and Malak, N. (2002) 'Core competence for sustainable competitive advantage: a structured methodology for identifying core competence', IEEE Transactions on Engineering Management, Vol. 49, No. 1, pp.28-35.

Halikias, J. and Panayotopoulou, L. (2003) 'Chief executive personality and export involvement', Management Decision, Vol. 41, No. 4, pp.340-349.

Hamel, G. and Prahalad, C.K. (1994) Competing for the Future, Harvard Business School Press, Boston.

Henderson, R. and Cockburn, I. (1994) 'Measuring competence? Exploring firm effects in pharmaceutical research', Strategic Management Journal, Vol. 15, pp.63-75.

Hood, J.N. and Young, J.E. (1993) 'Entrepreneurship's requisite areas of development: a survey of top executives in successful entrepreneurial firms', Journal of Business Venturing, Vol. 8, No. 2, pp.115-136.

Ireland, R.D., Hitt, M.A. and Sirmon, D.G. (2003) 'A model of strategic entrepreneurship: the construct and its dimensions', Journal of Management, Vol. 29, No. 6, pp.963-989.

Javidan, M. (1998) 'Core competence: what does it mean in practice?', Long Range Planning, Vol. 31, No. 1, pp.60-71. 
Johannisson, B. (1993) 'Entrepreneurial competences and learning strategies', in Larsson et al. (Eds.): Research in Strategic Change, pp.77-99, Lund University Press, Lund.

Knight, G. A., and Cavusgil, S. T. (2004) 'Innovation, organizational capabilities, and the born-global firm', Journal of International Business Studies, Vol. 35, No. 2, pp.124-141.

Kraus, S., Kauranen, I. and Reschke, C.H. (2011) 'Identification of domains for a new conceptual model of strategic entrepreneurship using the configuration approach', Management Research Review, Vol. 34, No. 1, pp.58-74.

Krauss, S.I., Frese, M., Friedrich, C. and Unger, J.M. (2005) 'Entrepreneurial orientation: a psychological model of success among southern African small business owners', European Journal of Work and Organizational Psychology, Vol. 14, No. 3, pp.315-344.

Lerner, M. and Almor, T. (2002) 'Relationships among strategic capabilities and the performance of women-owned small ventures', Journal of Small Business Management, Vol. 40, No. 2, pp.109-125.

Levitt, T. (1960) 'Marketing myopia', Harvard Business Review, Vol. 38, No. 4, pp.45-57.

Levitt, T. (2004) 'Marketing myopia', Harvard Business Review, Vol. 82, Nos. 7-8, pp.138-149.

Ljungquist, U. (2006) 'How do core competencies discriminate? Identification of influencing similarities and differences', Knowledge and Process Management, Vol. 14, No. 4, pp.237-247.

Ljungquist, U. (2007) 'Core competency beyond identification: presentation of a model', Management Decision, Vol. 45, No. 3, pp.393-402.

Ljungquist, U. (2008) 'Specification of core competence and associated components: a proposed model and a case illustration', European Business Review, Vol. 20, No. 1, pp.73-90.

Man, T.W.Y. and Lau, T. (2000) 'Entrepreneurial competencies of SME owner/manager in the Hong Kong services sector: a qualitative analysis', Journal of Enterprising Culture, Vol. 8, No. 3, pp.235-255.

Man, T.W.Y., Lau, T. and Chan, K.F. (2002) 'The competitiveness of small and medium enterprises: a conceptualization with focus on entrepreneurial competencies', Journal of Business Venturing, Vol. 17, No. 2, pp.123-142.

March, J.G. (1991) 'Exploration and exploitation in organizational learning', Organization Science, Vol. 2, No. 1, pp.71-87.

McDermott, M. (2003) An Empirical Investigation of Core Competency and Firm Performance, State University of New York Press, Albany.

McGaughey, S.L. (1998) 'Realising the marketing advantages of international standard-setting activities: opportunities for innovative technology-based SMEs', Journal of Marketing Management, Vol. 14, No. 8, pp.897-926.

McGrath, R.G. and MacMillan, I.C. (2000) 'The entrepreneurial mindset', Strategies for Continuously Creating Opportunity in an Age of Uncertainty, Harvard Business School Press, Cambridge.

Miles, M. and Huberman, M. (1994) Qualitative Data Analysis: An Expanded Sourcebook, SAGE Publications, Thousand Oaks.

Mitchelmore, S. and Rowley, J. (2010) 'Entrepreneurial competencies: a literature review and development agenda', International Journal of Entrepreneurial Behaviour \& Research, Vol. 16, No. 2, pp.92-111.

Nelson, R. and Winter, S. (1982) An Evolutionary Theory of Economic Change, Belknap Press, Cambridge.

Oviatt, B.M. and McDougall, P.P. (1994) 'Toward a theory of international new ventures', Journal of International Business Studies, Vol. 25, No. 1, pp.45-64.

Oviatt, B.M. and McDougall, P.P. (1995) 'Global start-ups: entrepreneurs on a worldwide stage', The Academy of Management Executive, Vol. 9, No. 2, pp.30-44. 
Pacitto, J.C., Julien, P.A. and Bizeul, P. (2007) 'Marketing in medium-sized manufacturing firms: the state-of-the-art in France and in Quebec', International Entrepreneurship and Management Journal, Vol. 3, No. 1, pp.29-50.

Penrose, E. (1959) The Theory of the Growth of the Firm, Oxford University Press, Oxford.

Petts, N. (1997) 'Building growth on core competences: a practical approach', Long Range Planning, Vol. 30, No. 4, pp.551-561.

Potter, J.W. (1996) An Analysis of Thinking and Research About Qualitative Methods, Lawrence Erlbaum Associates Inc., New Jersey.

Prahalad, C. K., and Hamel, G. (1990) 'The core competence of the corporation', Harvard Business Review, Vol. 68, No. 3, pp.79-92.

Rangone, A. (1999) 'A resource-based approach to strategy analysis in small-medium sized enterprises', Small Business Economics, Vol. 12, No. 3, pp.233-248.

Roberts, E.B. and Senturia, T.A. (1996) 'Globalizing the emerging high-technology company', Industrial Marketing Management, Vol. 25, No. 6, pp.491-506.

Rouse, M.J. and Daellenbach, U.S. (1999) 'Rethinking research methods for the resource-based perspective: isolating the sources of sustainable competitive advantage', Strategic Management Journal, Vol. 20, No. 5, pp.487-494.

Schulz, A., Borghoff, T. and Kraus, S. (2009) 'Towards a theory of SME internationalization', International Academy of Business and Economics Summer Conference, 5-7 June 2009, Thessaloniki, Greece.

Spreen, M. (1992) 'Rare populations, hidden populations and link-tracing designs: what and why?', Bulletin Methodologie Sociologique, Vol. 36, pp.34-58.

Tang, Z., Kreiser, P.M., Marino, L., Dickson, P. and Weaver, K.M. (2009) 'A hierarchical perspective of the dimensions of entrepreneurial orientation', The International Entrepreneurship and Management Journal, Vol. 5, No. 2, pp.181-201.

Wang, Y., Lo, H.P. and Yang, Y. (2004) 'The constituents of core competencies and firm performance: evidence from high-technology firms in China', Journal of Engineering and Technology Management, Vol. 21, No. 4, pp.249-280.

Winter, S.G. (2003) ‘Understanding dynamic capabilities', Strategic Management Journal, Vol. 24, No. 10, pp.991-995.

Yang, B.C., Wu, B.E., Shu, P.G. and Yang, M.H. (2006) 'On establishing the core competency identifying model: a value-activity and process oriented approach', Industrial Management \& Data Systems, Vol. 106, No. 1, pp.60-80.

Yin, R.K. (2003) Case Study Research: Design and Methods, SAGE Publications, Beverly Hills.

\section{Notes}

1 International new ventures (INVs) are defined as a firm that right from its birth seeks a competitive advantage by using resources from several countries and by selling its products in several countries (Oviatt and McDougall, 1994). While the term INV has likely been the most popular and used terminology for explaining the phenomenon of companies internationalising from interception, other names such as born global (Knight and Cavusgil, 2004; Ghannad and Andesson, 2012), global start-ups (Oviatt and McDougall, 1995), micro multinational enterprises - MMNE - (Dimitratos et al., 2003), high technology start-ups - HTSU - (Burgel and Murray, 2000), global high-tech firms (Roberts and Senturia, 1996). Instant internationals (Fillis, 2001) have also been used for designing these firms, see Kraus et al. (2011) for review. In this study, the term INV, Global start-ups or only start-ups will be used interchangeably.

2 An entrepreneur may adopt one of several business models. Here, we will concentrate on technological, in other words goods-producing firms. 
3 In an academic sense, we do have a reasonable understanding of the generic managerial competencies that entrepreneurs possess to capitalise on an opportunity and to ensure venture performance (Chandler and Hanks, 1994a). Pro-activeness, for instance, which involves risk-taking aspects and innovative ways to utilise opportunities in the environment, is suggested as the driving component of the entrepreneurial process in SMEs (Tang et al., 2009). Yet, although we acknowledge the entrepreneurial process in this paper, we do not intend to penetrate it per se. Instead, we will investigate whether core competence conceptions are parts of that process.

4 By 'main components' is here meant core competence and associated concepts such as resource, capabilities and (regular) competence. For a review, see Ljungquist (2008).

5 A technology-focused company is here defined as being product-oriented, that is the aim of the company is primarily to improve a product's characteristics and to sell the products, which is in line with Levitt's 'marketing myopia' $(1960,2004)$. A market focused company is here defined as being market-oriented, in other words the aim of the company is primarily to improve its strategic marketing and competitive position in the market, including developing customer relations and ultimately satisfying their needs.

6 The exact separation between a core competence and a competence often calls for rigorous empirical investigation, including customer reviews. In a very small firm, like a start-up, which normally only possess one or a few competencies, we assume the firm only has a single core competence. This assumption may not be very controversial, since large companies with tens of thousands of employees normally only have a few core competences.

7 Tillväxtverket (former NUTEK), the Swedish Agency for Economic and Regional Growth, is Sweden's public authority on industrial policy issues. Their task is to promote sustainable growth throughout the country. 